\title{
MAX Dimerization Protein 1
}

National Cancer Institute

\section{Source}

National Cancer Institute. MAX Dimerization Protein 1. NCI Thesaurus. Code C28627.

Max dimerization protein 1 (221 aa, $\sim 26 \mathrm{kDa}$ ) is encoded by the human MXD1 gene. This protein is involved in the negative regulation of transcription. 